Deák, George. “Andaházy-Szeghy Viktor, Györgyi Kalavszky, et al. eds. 2015. Hadikrónika 1939-1945:

kézzelfogható hadtörténelem ['War Chronicle 1939-1945: Tangible Military History']. Budapest: Zrinyi. 68 pp. +2

DVDs +79 reproduced documentary inserts." Hungarian Cultural Studies. e-Journal of the American Hungarian

Educators Association, Volume 11 (2018) DOI: 10.5195/ahea.2018.334

\title{
Andaházy-Szeghy Viktor, Györgyi Kalavszky, et al. eds. 2015. Hadikrónika 1939-1945: kézzelfogható hadtörténelem ['War Chronicle 1939-1945: Tangible Military History']. Budapest: Zrinyi. 68 pp. +2 DVDs + 79 reproduced documentary inserts.
}

\section{Reviewed by George Deák ${ }^{*}$, Independent Scholar}

Marching along in the footsteps of the book on World War I that I reviewed for this journal's Volume 10 (2017) (http://ahea.pitt.edu/ojs/index.php/ahea/article/view/286), the present volume presents the military history of World War II to the non-specialist Hungarian reader, who may be a descendent or younger relative of one of the 350-360,000 members of the Hungarian Honvédség ['Defense Forces'] counted among the losses described in this book - or perhaps a younger reader who needs motivation to join the NATO-integrated, volunteer Hungarian Army of today. Like its predecessor in the series of Kézzelfogható hadtörténelem ['Tangible Military History'], the book contains pictures, foldouts and removable documents, as well as a set of video interviews and presentations with impressive historical film footage. The discussions with historians from the Hungarian Museum of Military History in the videos are led by Sándor Szakály, director of the Veritas Research Institute for History formed in 2014 by the Fidesz government "with the explicit goal of studying and reevaluating the historical research of Hungary's past one hundred fifty years" (http://www.veritasintezet.hu/en/).

The book evidently and explicitly reflects the ideological orientation of the current regime, a key aim of which is to strengthen Hungarian national pride by overcoming the burden of guilt with which those who executed the disastrous and murderous policies of the Hungarian government during WW II were saddled during much of the Communist period. Guilt is therefore replaced in this book by a positive view of the bravery and ingenuity with which Hungary's rank and file soldiers served their country, regardless of whether the top political leaders made the right decision in taking Hungary into war against the Soviet Union or not. The foreword by Speaker of the National Assembly László Kövér states: "For the most part, it was only fifty years after the battles had ended that works could appear which, unlike the pummeling and condemning opinions of the past, could present the struggles of the soldiers and the tribulations of the home-front in a way that accords with the facts" ['Többségében csak fél századdal a harcok után jelenhettek meg azon müvek, amelyek az addig sulykolt elmarasztaló véleményekkel szemben a magyar katonák küzdelmét és a hátország lakosságának a megpróbáltatásait a tényeknek megfelelöen mutathatták be'] (3). In practice, the book achieves this goal by selecting the facts that support the desired message and omitting or soft-pedaling the

*deakgy62@gmail.com

$($ (c) $)$ EY

ULIS D-Senk
New articles in this journal are licensed under a Creative Commons Attribution 4.0 International License.

This journal is published by the University Library System of the University of Pittsburgh as part of its D-Scribe Digital Publishing Program and is cosponsored by the University of Pittsburgh Press 
Deák, George. “Andaházy-Szeghy Viktor, Györgyi Kalavszky, et al. eds. 2015. Hadikrónika 1939-1945:

kézzelfogható hadtörténelem ['War Chronicle 1939-1945: Tangible Military History']. Budapest: Zrinyi. 68 pp. +2

DVDs + 79 reproduced documentary inserts." Hungarian Cultural Studies. e-Journal of the American Hungarian

Educators Association, Volume 11 (2018) DOI: 10.5195/ahea.2018.334

facts that contradict it. At the very beginning, guilt is shifted to the victors of World War I. We are told that the treaties ending that war törvényszerüen ['inevitably'] gave rise to the struggle for revenge on the part of the defeated powers. There is little or no attempt to show which social groups had the greatest interest in keeping revisionism of the admittedly unjust peace treaties on the front burner, or in sidelining at home or through exile those voices that counseled a more conciliatory policy of revision; or how anti-Semitism, which was made politically respectable by the Numerus Clausus law of 1920, predisposed a large part of the population and the political class to eventually follow Hitler's lead to territorial aggrandizement and racial purification.

But, to be fair, for a popularizing work the textual presentation of the background of the war is quite sophisticated. The military historians who put this book together are experts in their specialties, and some, like Péter Szabó, who appears in some of the interviews, are widely cited by other historians in the field. The textual part of the book (more so than the images and videos) makes some effort at being even-handed. We are told (in a single sentence) that a minority of the politically well-connected, who included not only the obviously vulnerable Jewish industrial and financial elite but also former Prime Minister István Bethlen and Regent Miklós Horthy's two sons, were eager not to follow Hitler's lead. Later, in a short section on the labor battalions, the book pays lip service to the örök szégyeny ['eternal shame'] incurred by the Hungarian Army for its treatment of Jews and other elements - certain nationalities and political inclinations - held to be untrustworthy (47). The section on the medical corps rightly points out that the shortage of doctors was exacerbated by the fact that Jewish doctors were not allowed to use their rare skills but were instead forced to do physical labor in Military Labor Service.

The book's primary focus is on the presentation of various aspects of Hungary's military efforts and organization in the period from the territorial re-annexations before June 1941, through the campaign in the Soviet Union, to the endgame in 1944-45: the bloody battle of Budapest, the escape of what was left of the Army to Germany and even the reorganization of the $u j$, demokratikus ['new, democratic'] (24) army as the Soviets took over the country. We are also treated to much information about the various specialized forces of the army, such as the infantry, the cavalry, the artillery, the parachutists and the air force, the medical services, as well as about uniforms, valor and self-sacrifice decorations and about the experiences of Hungarian POWs.

The story of the wartime experience of the Jewish civilian population is appended to the section on the home-front in two succinct, somewhat antiseptic paragraphs (without any of the emotionally shocking pictures of deportations) ending with German plenipotentiary to Hungary Edmund Veesenmayer's 1944 report to Hitler: "In round numbers, 430,000 sent to the territory of the Reich, 150,000 in military labor service. 200,000 [remain] in Budapest" (61). Granted, it was the staff of the Hungarian Interior Ministry, not the Ministry of Defence, that carried out most of the deportations under the guidance of a small German military force directed by Adolf Eichmann. The short shrift that this story is given may seem technically justified, but considering the role that anti-Semitism played in Hungary's willingness to follow Hitler's lead into the war and the poisonous effect its memory has had on Hungarian society ever since, this topic would have deserved more coverage. Other controversial topics are also omitted or sanitized. The book alludes to the deportation in September 1941 of about 20,000 Jews - some refugees, some Hungarian citizens - to Kamenetz-Podolsk in German-occupied Ukraine, but their fate is 
Deák, George. “Andaházy-Szeghy Viktor, Györgyi Kalavszky, et al. eds. 2015. Hadikrónika 1939-1945: kézzelfogható hadtörténelem ['War Chronicle 1939-1945: Tangible Military History']. Budapest: Zrinyi. 68 pp. +2 DVDs + 79 reproduced documentary inserts." Hungarian Cultural Studies. e-Journal of the American Hungarian Educators Association, Volume 11 (2018) DOI: 10.5195/ahea.2018.334

passed over in silence: about fifteen to sixteen thousand of them were executed by the Germans. Incidentally, Sándor Szakály, the interviewer on the DVDs, caused a major controversy by referring in January 2014 to this action in the same way as did its contemporaries, saying it was egy idegenrendészeti eljárás ['a police action against aliens']

(https://budapestbeacon.com/veritas-director-sandor-szakaly-apologizes-for-calling-deportationan-immigration-procedure/ accessed 6/28/2018).

For the most part, the actions of the Hungarian occupation forces in Ukraine are discussed in generalities that manage to draw a veil over them. Yet, these actions occurred within the geographical boundaries and genocidal context that Timothy Snyder has famously highlighted in Bloodlands - Europe between Hitler and Stalin (New York: Basic Books, 2010), though Snyder did not describe the role that Hungarian forces had played in these actions since that role was not well documented, especially to non-Hungarian speakers, at the time that Snyder's book was published. But by 2015 Hungarian historians certainly knew of Tamás Krausz and Éva Mária Varga's, A Magyar megszálló csapatok a Szovjetunóban, levéltári dokumentumok 1941-1947 ['The Hungarian Occupation Forces in the Soviet Union, Archival Documents 1941 1947'] (Budapest: L'Harmattan, 2013) and Krisztián Ungváry's Magyar megszálló csapatok a Szovjetunióban, 1941-1944 ['Hungarian Occupation Forces in the Soviet Union, 1941-1944'] (Budapest: Osiris, 2015). While Krausz and Ungváry debated magnitude and certain aspects of the attrocities, it was clear that the participation of the Hungarian forces in the genocidal occupation included such diverse tasks as fighting against partisans, extreme collective punishments for local populations suspected of supporting the partisans, guarding Soviet POWs, and at times assisting in the early Holocaust by rounding up Jews, leading them to their execution sites, and covering the mass graves into which the Germans shot them before the eyes (and sometimes the secret cameras) of the Hungarian soldiers. The reader is not only denied information in the volume under review about the enormity of the suffering of the victims, but also about the reactions of the Hungarian soldiers who participated, witnessed, recorded, or even merely heard about these activities. Krisztián Ungváry describes the eagerness with which some soldiers participated, the revulsion and crying fits of others, and the indiffernce of many, as they were all conditioned by years of vitriolic propaganda to ignore the humanity of the "enemy." As for the Soviet POWs, we are not told that Hitler and other Nazi leaders explicitly planned to eliminate them through starvation and other means, and that indeed, several million Soviet POWs died in captivity (as claimed by Ungváry on p. 45 of his book), sometimes under the gaze of Hungarian troops. For details, the interested reader may see the rather cynical diary of one Hungarian officer in charge of guarding the dying POWs (Ungváry, 47, and also 216-226, 242).

The tangible military history of WWII does contain implied critiques of the military and political leaders who exposed Hungarian soldiers to situations of likely defeat and high casualty rates. The authors point out that Infantry General Henrik Werth strongly urged military cooperation with Germany on the eve of the German invasion of the Soviet Union. We learn that in the final analysis, the decision to invade the Soviet Union had to be made by Horthy, "one of the original fighters, going back to 1919, against bolshevism" ['aki egyike volt a bolsivizmus ellen küzdöknek (még 1919-ben)'] (5), a past that, it is implied correctly, influenced his decision of 1941. One frequent refrain in this book is that the soldiers were given assignments for which they were not equipped. Horthy's belated attempt to surrender to the Soviets and switch sides in 
Deák, George. “Andaházy-Szeghy Viktor, Györgyi Kalavszky, et al. eds. 2015. Hadikrónika 1939-1945:

kézzelfogható hadtörténelem ['War Chronicle 1939-1945: Tangible Military History']. Budapest: Zrinyi. 68 pp. +2

DVDs +79 reproduced documentary inserts." Hungarian Cultural Studies. e-Journal of the American Hungarian

Educators Association, Volume 11 (2018) DOI: 10.5195/ahea.2018.334

October 1944 is also shown to have been doomed to failure, although the reasons for this failure, namely, the ideological commitment of much of the officer corps to the extreme right, is not mentioned (19).

In summary, this work may teach present-day readers about some of the experiences of their forefathers and impart sympathy for their elders' suffering, as well as engender pride for the patriotism and valor that some troops displayed in battle. But it does not go far enough to help readers understand and acknowledge the mistaken steps of the past. Bad decisions and actions were committed in part on the basis of the false notions that each community in the region, whether within Hungary or outside it, had of its neighbors and fellow nationals, notions which these communities held with fierce pride. False ideas spread easily, and when politicians exploit them as an instrument of rule, the results are disastrous. This is a lesson that should have also been communicated by a book intended for a general present-day, possibly young audience wishing to know more about the history of World War II. 